\title{
Book Review: A Portrait of the Analyst
}

Michael B. Knable, D.O.

St. Elizabeth's Hospital, Washington DC

Follow this and additional works at: https://jdc.jefferson.edu/jeffjpsychiatry

Part of the Psychiatry Commons

Let us know how access to this document benefits you

\section{Recommended Citation}

Knable, D.O., Michael B. (1988) "Book Review: A Portrait of the Analyst," Jefferson Journal of Psychiatry. Vol. 6 : Iss. 2 , Article 14.

DOI: https://doi.org/10.29046/JJP.006.2.014

Available at: https://jdc.jefferson.edu/jeffjpsychiatry/vol6/iss2/14

This Article is brought to you for free and open access by the Jefferson Digital Commons. The Jefferson Digital Commons is a service of Thomas Jefferson University's Center for Teaching and Learning (CTL). The Commons is a showcase for Jefferson books and journals, peer-reviewed scholarly publications, unique historical collections from the University archives, and teaching tools. The Jefferson Digital Commons allows researchers and interested readers anywhere in the world to learn about and keep up to date with Jefferson scholarship. This article has been accepted for inclusion in Jefferson Journal of Psychiatry by an authorized administrator of the Jefferson Digital Commons. For more information, please contact: JeffersonDigitalCommons@jefferson.edu. 


\title{
A Portrait of The Analyst
}

\author{
A MIND OF HER OWN: THE LIFE OF KAREN HORNEY \\ Susan Quinn \\ New York, Summit Books
}

Michael B. Knable, D.O.

\begin{abstract}
Although Karen Horney's works are certainly among the most popular ever composed by a psychoanalyst, it has previously been difficult for many residents to adequately evaluate her contributions to the field. One could speculate that Horney's work has been received with the prejudicial reading that often accompanies an author laboring under the reputation of a maverick, and indeed a major theme of this biography is the trouble Horney encounters in her stubborn pursuit of truth as her own clinical and personal experiences would dictate it to be. Despite Quinn's obvious admiration for her subject's individualism and pioneering consideration of female psychology, this volume examines Horney's life and work with an approach objective enough to reveal the depth of her thought. A colorful picture of Horney's humanity emerges as well.

Biography of great psychiatric thinkers is often apt to become psychobiography. The examination of Freud's own personal and cultural experience for example, has contributed much to understanding the development of his thought. Accounts of Horney's childhood have survived in a collection of diaries from which Quinn has drawn extensively. We glimpse the young Horney's feelings about an often absent sea captain father, her strong identification with early teachers and her struggles with adolescent romance. This first section of the book is the most cumbersome, perhaps because the rich material wrom childhood is presented in some detail but interpreted only rather briefly. Further psychobiographical speculation is difficult when Horney's own feelings about her past do not seem to be available, but such an essay would have been interesting, especially in light of Quinn's exhaustive repertoire of source material.

Perhaps the most interesting pattern to emerge from Quinn's book reveals Horney's tendency to attach to, and then separate from, the institutions and people she encountered in life. Admittedly, Horney's development as a theorist set her apart from the strong orthodoxy that had arisen in American psychoanalysis. Quinn portrays the personal motives that may also have driven Horney to frequent separations. One wonders though, what deeper issues may have fueled Horney's abandonment of: her marriage, Franz Alexander and the Chicago Institute, Lawrence Kubie and the New York Institute, and the consensus within her own Association for the Advancement of Psychoanalysis. Interestingly, Alexander, and especially Kubie, appear in this retelling as rigid
\end{abstract}


dogmatists with sly political savvy, perhaps deservedly so, and this may explain a person like Horney's distaste for them as bosses. They bring to mind Horney's theocratic father. It is more difficult to explain why Horney resisted the affiliation of her own Association with New York Medical College, or why Erich Fromm would be excluded from the Association as a "non-medical" analyst, when he was at least trustworthy enough to analyze Horney's daughter Marianne. Horney's own romantic feelings often enter into these disputes and we learn of her painful affairs with Fromm and with supervisees in Chicago and New York. A picture emerges of an immensely gifted woman who suffers from her conflicting desires to become an independent thinker and to gain acceptance by the reigning establishment.

There is much discussion of historical and cultural forces that impacted on Horney's career, and these sections make for fascinating reading. The relationships between Weimar Germany, psychoanalysis, and contemporary opportunities for women are explored and in this context it seems doubly remarkable that Horney, one of the first female medical students in Germany, also possessed the fortitude to embrace the fledgling discipline of analysis from within the Kraepelinian orientation of the times. Later we are intrigued by Horney's negative view of her daughters' analysis with Melanie Klein. For a psychiatric resident there is much that is extremely enlightening in Quinn's sympathetic but careful treatment of Horney's major works. Also, the cast of characters that contributes to the seething political environment between American psychoanalytic institutes (most notably New York and Baltimore-Washington) provides the student with a great overview of the history of analysis in this country. We also get some feeling of what it must have been like to be amongst the wave of immigrating European intellectuals (bei Unsers) between the world wars, and sense the determination with which they erected new institutions.

In sum, I believe any resident interested in psychotherapy, and psychoanalysis in particular, will find this book extraordinarily informative and provocative. Not only are Horney's contributions given a thoughtful exegesis but we see as well her superhuman strengths and very human weaknesses as determinants in her tremendously interesting life. 